\title{
219. Acetaminoacylase and its Implication to Protein Biosynthesis
}

\author{
By Susumu Tsunazawa,*) Kozo Narita,**) and Kikuo OgatA*)
}

(Comm. by Shiro AkAbori, M. J. A., Nov. 12, 1970)

A working hypothesis that the $\mathrm{N}$-terminal acetylated amino acid residue functions as the initiator of protein biosynthesis has been presented by Narita. ${ }^{1)}$ We have studied ovalbumin synthesis using hen's oviduct system to verify above hypothesis and have reported evidence that acetylglycyl-tRNA served as the initiator of ovalbumin biosynthesis. $^{2), 3)}$ Another evidence to support our hypothesis has been presented by Liew, Haslett and Allfrey, ${ }^{4)}$ showing the participation of acetylseryl-tRNA in the initiation of histone synthesis in the regenerated rat liver. The majority of proteins, however, synthesized in cytoplasms of eukaryotes have free amino terminal residues. These facts can be reasonably explained by assuming the existence of an enzyme in cytoplasms which remove acetyl or acetylaminoacyl group from the terminal acetylated polypeptides attached to ribosomes or from the detached acetylated proteins from ribosomes.

Thus we have attempted to search for such an enzyme from rat liver which is known to synthesize serum ablumin ending acetyl-free $\mathrm{N}$-terminal glutamic acid residue. ${ }^{5)}$ We used acetylmethionine and acetylmethionylthreonine (Ac-Met-Thr) as substrates to look for such an enzyme, since an acetylamino acid deacetylase preferential for acetylmethionine and acetylleucine was shown to be present in the supernatant fraction of rat liver homogenate. ${ }^{6)}$ The supernatant of the rat liver homogenate after centrifugation at $10,000 \times \mathrm{g}$ for $20 \mathrm{~min}$ was found to contain an enzyme (s) to hydrolyze both the substrates. Therefore fractionation of the enzyme was carried out. The proteins possessing the enzyme activity were precipitated between 20 and $50 \%$ $\left(\mathrm{NH}_{4}\right)_{2} \mathrm{SO}_{4}$ saturation and the precipitates were dissolved in $\mathrm{M} / 500$ phosphate buffer of $\mathrm{pH} 7.2$ containing $0.2 \mathrm{M} \mathrm{NaCl}$. The supernatant after heating the solution at $60^{\circ} \mathrm{C}$ for $5 \mathrm{~min}$ was then chromatographed on a DEAE-cellulose column as shown in Fig. 1.

The enzyme specific for the acetylamino acid (acetylamino acid deacetylase) was clearly separated from the enzyme for the acetyldipeptide. The reaction mixture of Ac-Met-Thr with the latter enzyme contained acetylmethionine and threonine as the products. This

*) Niigata University Medical School, Niigata.

**) Institute for Protein Research, Osaka University, Osaka. 


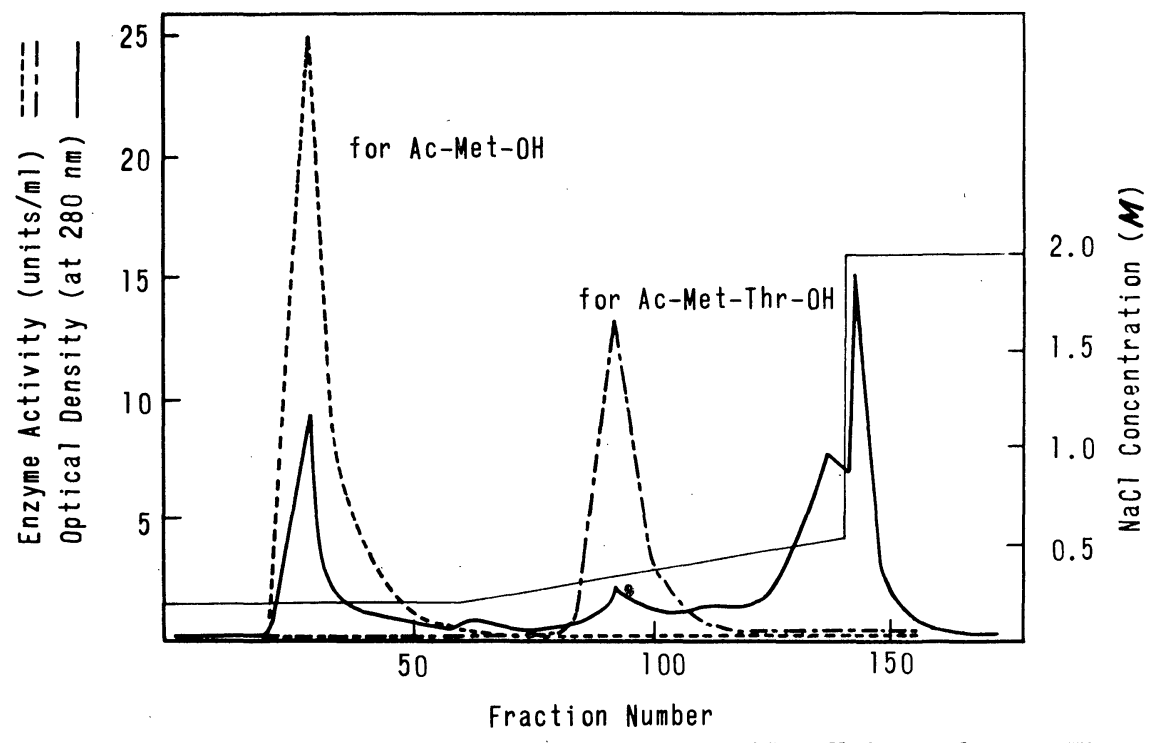

Fig. 1. Elution of acetaminoacylase from a DEAE-cellulose column. Heattreated supernatant of the rat liver homogenate containing $976 \mathrm{mg}$ of protein (see the text) was placed on a $2.5 \times 83 \mathrm{~cm} \mathrm{DEAE-cellulose} \mathrm{column} \mathrm{which} \mathrm{had}$ been equilibrated with $0.2 \mathrm{M} \mathrm{NaCl}-0.005 \mathrm{M}$ sodium phosphate buffer, $\mathrm{pH}$ 7.2. After washing the column with a column volume of initial buffer, a linear gradient elution was carried out with $0.2 \mathrm{M}-0.6 \mathrm{M} \mathrm{NaCl}$ in $0.005 \mathrm{M}$ sodium phosphate buffer, $\mathrm{pH}$ 7.2. The column was finally washed with $2 \mathrm{M} \mathrm{NaCl}$ $0.005 \mathrm{M}$ - sodium phosphate buffer, $\mathrm{pH} 7.2$. Fractions (about $15 \mathrm{ml}$ ) were assayed with Ac-Met-Thr (- - - ) and acetylmethionine (-----) as substrates. Protein (—) was determined by the absorbancy at $280 \mathrm{~nm}$.

result suggested the possibility that the enzyme might be a carboxypeptidase. However, from the incubation mixture of acetylmethionylthreonine methylester or acetylmethionylthreonine amide, acetylmethionine and the threonine ester or threonine amide were detected. Therefore the enzyme may not be a carboxypeptidase but an acetaminoacylase in nature. In order to confirm nature of the enzyme, effects of the enzyme on several synthetic acetylated peptides were examined. It is evident from Table I that the present enzyme is an acetaminoacylase which liberates acetylamino acids from the N-acetylpeptides. Table I further shows that the reaction rate is affected by the nature of the terminal acetylamino acid; namely acetylmethionylpeptides were the best substrates among examined. Formylmethionylthreonine was also hydrolyzed by the enzyme in an appreciable rate.

Next, we have studied effects of the present acetaminoacylase on protein substrates. In this case the enzyme purified further by chromatography on a hydroxylapatite column followed by gel filtration on a Sephadex G-200 column, was used. As protein substrates, hen's ovalbumin having Ac-Gly-Ser-Gly-Ile-Ala- sequence at its N- 
Table I. Relative Hydrolysis Rates of Acetylpeptides by the Enzyme

Enzyme activity was measured in a total volume of $0.5 \mathrm{ml}$ buffered at $\mathrm{pH}$ $7.2\left(0.05 \mathrm{M} \mathrm{Na}\right.$-phosphate) after incubation for 1 hour at $37.5^{\circ} \mathrm{C}$. The relative values listed are based on the rate of hydrolysis of Ac-Met-Thr selected to be 100. Ac-Met-Thr was hydrolyzed at a rate of $0.72 \mu \mathrm{mole} /$ hour by this enzyme preparation

\begin{tabular}{lcl}
\hline \multicolumn{1}{c}{ Substrate* $^{c}$} & $\begin{array}{c}\text { Relative hydrolysis } \\
\text { rate }\end{array}$ & \multicolumn{1}{c}{ Main products } \\
\hline Ac-Met-Thr & 100 & Ac-Met and Thr \\
Ac-Met-Thr-OCH & 28.7 & Ac-Met and Thr-OCH \\
Ac-Met-Thr-NH & 65.0 & Ac-Met and Thr-NH $\mathrm{NH}_{2}$ \\
Formyl-Met-Thr & 26.6 & Formyl-Met and Thr \\
Ac-Gly-Ser & 13.8 & Ac-Gly and Ser \\
Ac-Leu-Ala-Gly & 62.5 & Ac-Leu and Ala-Gly \\
Ac-Phe-Gly-Phe & 27.5 & Ac-Phe and Gly-Phe \\
Ac-Ala-Leu & 0 & none \\
Ac-Gly-Asp-Val-Gly & 0 & none \\
Ac-Met & 0 & none \\
Ac-Gly & 0 & none \\
\hline
\end{tabular}

* Ac-Met-Thr- $\mathrm{OCH}_{3}$ and Ac-Met-Thr- $\mathrm{NH}_{2}$ represent respectively acetylmethionylthreonine methylester and acetylmethionylthreonine amide.

terminus, ${ }^{7)}$ baker's yeast cytochrome c possessing Thr-Glu-Phe-Lyssequence ${ }^{8)}$ and its acetylated derivative with ${ }^{14} \mathrm{C}$-acetic anhydride were used. When native ovalbumin was digested with the enzyme, small amounts of serine $(0.027 \mathrm{~mole} / \mathrm{mole}$ of ovalbumin $)$, isoleucine ( 0.025 mole) and alanine $(0.033$ mole $)$ appeared as the $\mathrm{N}$-terminal groups by the dinitrophenylation method, suggesting that the terminal acetylglycine was liberated. DNP-Glycine seemed to be decomposed during acid hydrolysis. Almost identical results were obtained with denatured ovalbumin, suggesting that liberation of acetylglycine and several amino acids was not due to the protein conformation. These results indicate that the present acetaminoacylase preparation may contain an aminopeptidase as a contaminant, which affects on free $\mathrm{N}$-terminal residue sequentially after the removal of the terminal acetylglycine. However, almost no threonine was released from the $\mathrm{N}$-terminal position of baker's yeast cytochrome c even after denaturation. In contrast to the unmodified yeast cytochrome, radioactive acetylthreonine was liberated from the acetylated cytochrome, confirming that the enzyme is an acetaminoacylase in nature and that the contaminating aminopeptidase, if it were really present, is affected its action by neighbouring amino acid residues of the terminus. Another explanation on the above results is that the present enzyme possesses dual activities, acetaminoacylase and aminopeptidase, in a molecule. When homogeneous enzyme preparation is obtained, ambiguous properties of the enzyme described above will be clarified. 
The present acetaminoacylase will act on the N-terminal acetylated nascent polypeptides attached to ribosomes during protein synthesis or the detached acetylated proteins from the ribosomes after the completion of the synthesis, if our assumption that protein biosynthesis in cytoplasms of eukaryotic organisms is initiated with acetylaminoacyl-tRNA, was the case. Amino acids may be regenerated by the action of acetylamino acid deacetylase from the released acylamino acids and may be used again as materials for protein synthesis in cytoplasms. In the case of naturally occurring acetylated proteins at their termini, three possibilities can be considered. The one is that the cells synthesizing acetylated proteins do not contain such an acetaminoacylase. ${ }^{1)}$ Cells to synthesize ovalbumin in hen's oviduct are probably this case, since the present rat liver enzyme hydrolyzed ovalbumin yielding acetylglycine in both native and denatured states. In fact, in the preliminary experiments, such enzyme activity in the $10,000 \times \mathrm{g}$ supernatant of hen's oviduct homogenate was about only $1 / 7$ of that in rat liver. The second is that the acetylated $\mathrm{N}$-terminus is imbedded in the molecule even during the growing of the polypeptide chains on ribosomes, and thus the enzyme cannot be accessible to the acetylated terminus although the cells contain acetaminoacylase. ${ }^{2)}$ The third case is that the cells contain the enzyme and the acetylated terminus is exposed on the surface of the protein molecule but the completed molecule still possesses an acetyl at the terminus. Vertebrate heart muscle cytochromes c are probably this case, since the enzyme gave no influence on synthetic Ac-Gly-Asp-Val-Glu, as shown in Table I, which is the $\mathrm{N}$-terminal peptide of cytochromes $\mathrm{c}$ from bovine, horse, etc., and since X-ray crystallographic analyses of horse heart and bonito cytochromes $\mathrm{c}$ demonstrated that the terminal peptide chains were exposed on the surface of their molecules.9)

Recent reports from several laboratories demonstrated that unsubstituted methionyl-tRNA $\mathrm{F}_{\mathrm{F}}$ participated in the initiation of polypeptide synthesis in cytoplasms from eukaryotic cells (reticulocytes, trout testis and wheat germ)..$^{10)-15}$ These papers seem to indicate that the mechanism of protein chain initiation in cytoplasm may be different from specific cell to others.

The present studies are aided in part by a scientific research grant from the Ministry of Education and by a grant from the Tanabe Amino Acid Foundation.

\section{References}

1) K. Narita: Seikagaku (J. Japanese Biochem. Soc.), 34, 79 (1962). 
2) K. Narita, I. Tsuchida, and K. Ogata: Biochem. Biophys. Res. Commun., 33, 430 (1968).

3) K. Narita, I. Tsuchida, S. Tsunazawa, and K. Ogata: Biochem. Biophys. Res. Commun., 37, 327 (1969).

4) C. C. Liew, G. W. Haslett, and V. G. Allfrey: Nature, 226, 414 (1970).

5) J. R. Sargent and P. N. Campbell: Biochem. J., 96, 134 (1965).

6) K. Narita, N. Sato, and K. Ogata: J. Biochem., 57, 176 (1965).

7) K. Narita and J. Ishii: J. Biochem., 52, 367 (1962).

8) K. Narita, K. Titani, Y. Yaoi, and H. Murakami: Biochim. Biophys. Acta, 77, 688 (1963).

9) R. E. Dickerson, T. Takano, D. Eisenberg, O. B. Kallai, L. Samson, A. Cooper, and E. Margoliash: to appear in J. Biol. Chem.

10) A. E. Smith and K. A. Marcker: Nature, 226, 607 (1970).

11) J. C. Brown and A. E. Smith: Nature, 226, 610 (1970).

12) S. Bhaduri, M. K. Chatterjee, K. K. Bose, and N. K. Gupta: Biochem. Biophys. Res. Commun., 40, 402 (1970).

13) J. P. Leis and E. B. Keller: Biochem. Biophys. Res. Commun., 40, 416 (1970).

14) R. Jakson and T. Hunter: Nature, 227, 672 (1970).

15) D. T. Wigle and G. H. Dixon: Nature, 227, 676 (1970). 